\title{
Distribution and growth of larval and adult Thysanoessa macrura (Euphausiacea) in the Bransfield Strait Region, Antarctica
}

\author{
Walter Nordhausen \\ Scripps Institution of Oceanography, La Jolla, California 92093-0208, USA
}

\begin{abstract}
Thysanoessa macrura was the most common euphausiid in the western Bransfield Strait region, with highest abundances of 5000 individuals per $1000 \mathrm{~m}^{3}$ in Gerlache Strait in December 1986 and 4500 ind. $1000 \mathrm{~m}^{-3}$ in January 1987 , which coincided temporally and spatially with the annual spring bloom of phytoplankton. With the progression of the austral summer, high larval abundances extended into Bransfield Strait, apparently advected there by the Bransfield Current, estimated both geostrophically and with Lagrangian drifters. A discrete spawning period prior to December 1986 gave rise to a distinct cohort which persisted through March 1987. The study area was highly variable in phytoplankton biomass. Waters of northern Gerlache Strait reached $25 \mathrm{mg} \mathrm{chl} \mathrm{a} \mathrm{m}^{-3}$ in January 1987,

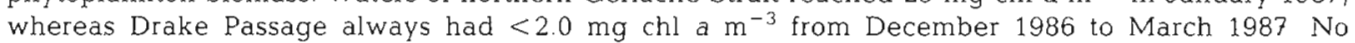
differences in development or growth rate were found in regions with different levels of algal biomass. The development time from calyptopis 2 to furcilia 6 was ca $90 \mathrm{~d}$. Larvae of T. macrura did not appear to perform diel vertical migration between the 0 to 100 and 100 to $200 \mathrm{~m}$ depth layers.
\end{abstract}

\section{INTRODUCTION}

The early concept of the Southern Ocean as being high in primary production has changed dramatically over the past decade. Recent evidence suggests that the productivity of Antarctic waters is similar to that of oligotrophic gyres of the oceans (Hempel 1985, Hewes et al. 1985, Smetacek et al. 1990). However, coastal regions with shallow mixed layers are characterized by high algal productivity and are thus of special importance in the life cycles of Antarctic zooplankton (Hewes et al. 1985, Holm-Hansen \& Mitchell 1991, Huntley et al. 1991).

All major zooplankton taxa occur in the Antarctic, but the bulk of the biomass consists of a few large copepod species and large stocks of euphausiids (Knox 1970, Hopkins \& Torres 1988, Smetacek et al. 1990 , Smith \& Schnack-Schiel 1990, Conover \& Huntley 1991). Thysanoessa macrura is the most consistently distributed euphausiid in Antarctic waters and frequently exceeds Euphausia superba in number (Baker 1954, Makarov 1979a, Kittel \& Stepnik 1983, Kittel et al. 1985, Piatkowski 1985a, Sebutal Pires 1986, Daly \& Macaulay 1988). The highest abundances of $T$. macrura have been observed between 0 and $200 \mathrm{~m}$ depth
(Hempel 1981, Loeb \& Shulenberger 1987) and diel vertical migration is reported not to occur (Kittel et al. 1985, Piatkowski 1985b, Lancraft et al. 1989). All stages are found in open water, but only postlarvae and adults have been observed to occur under pack ice (Daly \& Macaulay 1988).

Much of the life cycle of Thysanoessa macrura is unknown (Ward et al. 1990). Adult females are thought to reach maturity after 1 or possibly 2 yr (Fevolden 1979). Repetitive spawning during one season and in consecutive years cannot be excluded. Larvae of $T$. macrura appear in the upper $200 \mathrm{~m}$ of the water column early in austral spring (Makarov 1979a, Hempel \& Hempel 1982); a developmental ascent has been described for T. macrura (Makarov 1979a) which is similar to that of E. superba (Marr 1962). Nauplii and metanauplii prevailed in the deepest layers sampled between 1000 and $200 \mathrm{~m}$, above which they were practically absent (Makarov 1979a). Calyptopis 1 is the first stage to appear in the photic zone (Makarov 1982). Highest abundances of early life stages (nauplius, metanauplius, calyptopis and furcilia) have been found from September through March (Makarov 1979a, Hempel 1981)

Information on the type of food consumed by Thysa- 
noessa macrura is limited and contradictory. Nemoto \& Harrison (1981) suggest that $T$. macrura feeds on phytoplankton. However, Hopkins (1985) found a variety of food items in its gut, including some phytoplankton and euphausiid molts, and concluded that the species is primarily a predator on small zooplankton, especially crustaceans. The copepods Calanoides acutus and Metridia gerlachei were the most common identifiable food items. The anatomy of the thoracopods, and in particular the very long second thoracopod, is distinct from the feeding basket of other Antarctic euphausiids (Brinton pers. comm.). While the mouthparts of species of the genus Thysanoessa are suited for filter-feeding, capture of copepods through the rapid lateral spreading of the thoracic limbs has been described for $T$. longipes and $T$. inermis (Mauchline \& Fisher 1969).

The lipid composition of Thysanoessa macrura, which is very different from that of other euphausiids, supports this observation (Reinhardt \& Van Vleet 1986). T. macrura stores large amounts of wax esters and phospholipids, which are presumably used as energy reserves during winter and for gonad development in spring (Hagen 1988). This may be an indication that $T$. macrura does not feed during winter, unlike Euphausia superba (Marschall 1988), and may explain the early spawning.

This investigation was conducted as part of the RACER (Research on Antarctic Coastal Ecosystem Rates) program, which was specifically designed to study the dynamics which lead to the development and decline of the spring bloom and its effect on zooplankton assemblages in western Bransfield Strait and adjacent Gerlache Strait (Huntley et al. 1991). This region is known for its high primary productivity and may serve as a nursery area for zooplankton (El-Sayed 1984). The 4 sequential surveys covered broad spatial and temporal scales. This paper describes the abundance and distribution of larval and adult Thysanoessa macrura in a heterogeneous habitat. An attempt is made to relate the distribution and growth rates of larval $T$. macrura to the observed physical oceanography and primary production in highly different water masses.

\section{METHODS}

Study site. The RACER program (Research on Antarctic Coastal Ecosystem Rates) is a multi-disciplinary field study, designed to investigate the physical and biological processes which give rise to the observed high productivity west of the Antarctic Peninsula. The RACER pilot program (1986-87) studied mesoscale physical and biological dynamics of the spring bloom. Detailed measurements on the hydro- graphy, ocean optics, vertical flux, microbiology, and phyto- and zooplankton were made during four $2 \mathrm{wk}$ cruises between 15 December 1986 and 30 March 1987 in a $25000 \mathrm{~km}^{2}$ study area in the western Bransfield Strait region (Huntley et al. 1987, 1991).

Zooplankton sampling. A grid of 69 stations west of the Antarctic Peninsula in the waters of Drake Passage, Bransfield Strait, and Gerlache Strait (Fig. 1) was sampled from aboard RV 'Polar Duke' from December 1986 to March 1987. Basic physical, chemical, and biological observations were made at all 69 stations during 4 'fast grid surveys'. Zooplankton samples were taken by oblique bongo net tows to between 40 and $45 \mathrm{~m}$ depth. This was followed by a 'slow grid' of 25 stations evenly distributed over the same area. These stations were occupied for up to $24 \mathrm{~h}$ during which stratified net tows

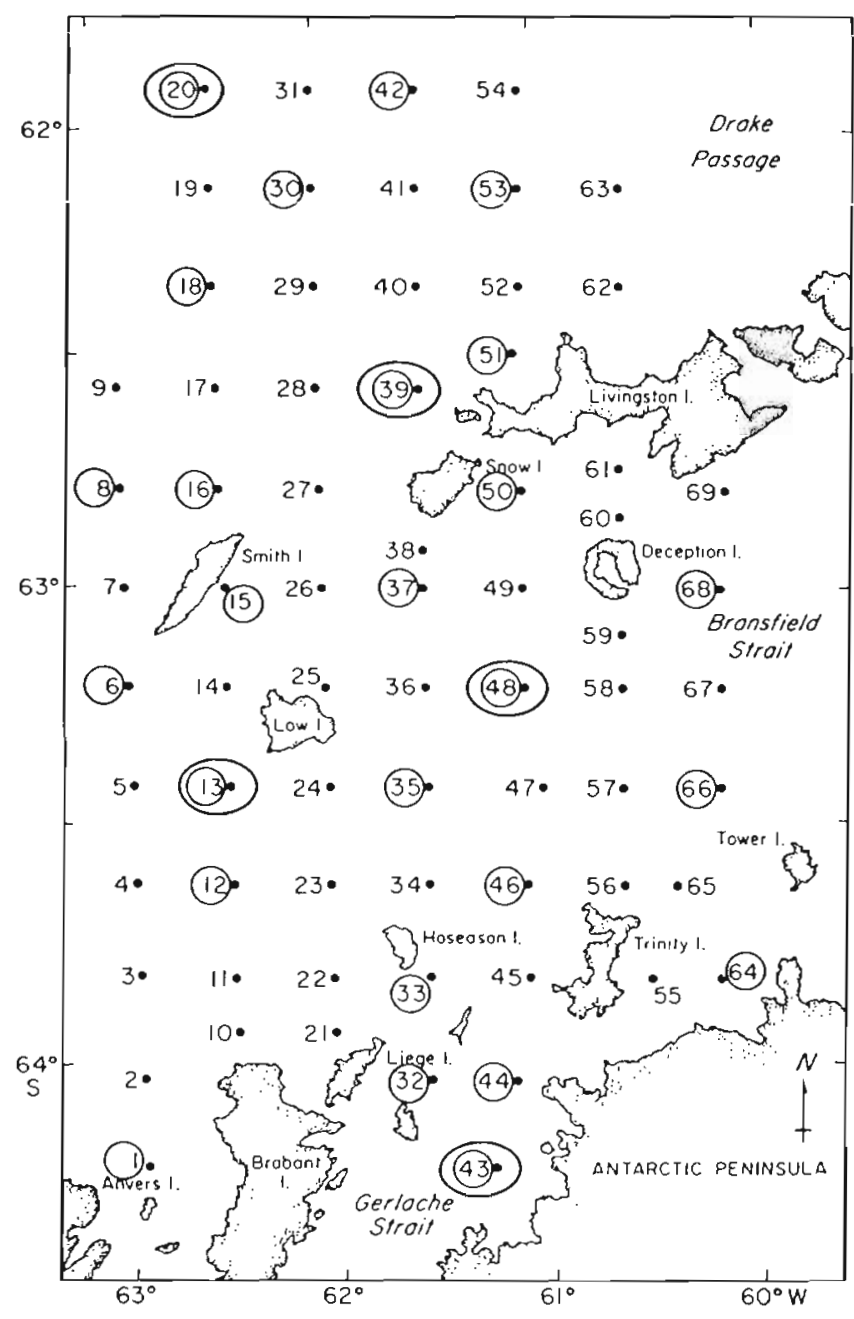

Fig. 1. Study area of RACER $1986-87$ The 'fast grids' included 69 stations. The 25 stations of the 'slow grid' (circled) were visited after the completion of the 'fast grid' Double-circled stations were $24 \mathrm{~h}$ stations; all others were sampled for 1 to 3 $h$. The slow and fast grids were completed 4 times between December 15, 1986 and March 30, 1987 
$(0$ to $100 \mathrm{~m}, 100$ to $200 \mathrm{~m}$ ) were taken using a doublemessenger, opening-closing net of $1 \mathrm{~m}^{2}$ diameter. Mesh size was $333 \mu \mathrm{m}$. Sampling was done at all times of day and night. The duration of darkness varied from about $3 \mathrm{~h}$ in December to about $10 \mathrm{~h}$ in March. The volume of water filtered was calculated from measurements made with TSK flowmeters. Samples were preserved in $5 \%$ buffered formalin for laboratory analysis. Depths permitting, deep tows were performed in some cases down to $2700 \mathrm{~m}$ (Stn 20).

All Thysanoessa macrura were identified and counted in samples collected. Abundances (individuais per $1000 \mathrm{~m}^{3}$ ) were calculated based on volume filtered calculated from flow meter readings. Specimens were measured to the nearest millimeter, from the tip of the rostrum to the tip of the telson, and classified by developmental stage (nauplius, metanauplius, calyptopis 1 to 3, furcilia 1 to 6, juveniles and adults (Rustad 1934, Makarov 1979b). For postlarvae of 10 to $13 \mathrm{~mm}$ the term 'juveniles' is used. Individuals larger than $14 \mathrm{~mm}$, roughly the onset of maturity, were sexed according to external characteristics.

Distinction between larvae of Thysanoessa macrura and $T$. vicina is difficult (Rustadt 1930, 1934, Ruud 1932, Nemoto 1966). However, adult T. vicina occur farther north and have not been reported south of $57^{\circ} \mathrm{S}$ (Lomakina 1964, Nemoto 1966, Makarov 1979a, Brinton 1985). This study was conducted between $62^{\circ}$ and $64^{\circ} 30^{\prime} \mathrm{S}$ and no $T$. vicina adults were found. Without a spawning population present and considering the northeast flow it is unlikely that larvae of $T$. vicina occurred in the study site.

\section{RESULTS}

\section{Abundance and distribution of larvae and adults}

Thysanoessa macrura was found throughout western Bransfield Strait and at all depths to $2700 \mathrm{~m}$. Only $6 \%$ of 202 analyzed samples of the slow grid did not contain T. macrura. Larvae were consistently most abundant in the upper $100 \mathrm{~m}$ (Mann-Whitney $U$-test, p < $0.05)$; there was no significant diel variation in larval abundance in either depth stratum (0 to $100 \mathrm{~m}$ and 100 to $200 \mathrm{~m}$ ) (Mann-Whitney $U$-test, $\mathrm{p}<0.05$ ).

The day and night net catches of Thysanoessa macrura during December 1986 through March 1987. normalized for duration of darkness, revealed no significant differences (Mann-Whitney $U$-test). In contrast, Euphausia superba showed diel catch differences, believed to be due to net avoidance by these larger organisms, which optically detect approaching nets during daytime (Brinton et al. 1987). Net avoidance appears to be less of a problem in abundance estimates of $T$. macrura than for the larger $E$. superba.

Thysanoessa macrura calyptopis and furcilia 1 (C1 to C3 and F1) stages were already abundant at the beginning of the study in late December Even though larvae were found at all stations, the abundance varied over 3 orders of magnitude with highest numbers of up to 5000 ind. $1000 \mathrm{~m}^{-3}$ in Gerlache Strait. Lowest abundances were found in the waters of Drake Passage $(80$ ind. $\left.1000 \mathrm{~m}^{-3}\right)$. Abundances of 300 to $1200 \mathrm{ind} .1000 \mathrm{~m}^{-3}$ in Bransfield Strait were greater than in the northwestern part of the study area (Fig. 2a).

A similar distribution was found during January, but the highest abundances (3700 to 4600 ind. $1000 \mathrm{~m}^{-3}$ were found over a larger area extending from Gerlache Strait into southern Bransfield Strait. Abundances of 100 to 1200 ind. $1000 \mathrm{~m}^{-3}$ were found in central Bransfield Strait, again with a gradient from northwest to southeast. Lowest abundances were still found at the northern stations in Drake Passage (Fig. 2b).

Distribution and abundance in the latter half of February 1987 were quite different. The abundance of larvae decreased to less than 1100 ind. $1000 \mathrm{~m}^{-3}$ with highest abundances in central Bransfield Strait. Abundances in Gerlache Strait (110 to 140 ind. $1000 \mathrm{~m}^{-3}$ ) were similar to those in western and southern Bransfield Strait. Lowest abundances were found again in northern Bransfield Strait and in Drake Passage (10 to 50 ind. $1000 \mathrm{~m}^{-3}$; Fig. 2c).

Abundances in March were lower than at any other time in the study period, with highest values in Gerlache Strait ( 360 ind. $1000 \mathrm{~m}^{-3}$ ). Larval abundances in other areas were $<70$ ind. $1000 \mathrm{~m}^{-3}$ (Fig. 2d).

Thysanoessa macrura adults were found in most samples from December through March. Their abundances did not exhibit the large variations observed for larvae. Highest abundances of adults were generally found in the northwestern part of the study area; the phytoplankton-rich Gerlache Strait never showed highest numbers (Fig. 3).

\section{Cohort analyses}

The composition and distribution of larval Thysanoessa macrura stage and length were analyzed to identify specific cohorts. The mean stage was calculated from:

$$
\mathrm{S}=[(\mathrm{C} 1 \times 1)+(\mathrm{C} 2 \times 2)+\ldots+(\mathrm{F} 6 \times 9)] / \mathrm{N}
$$

where $\mathrm{S}=$ mean stage; $\mathrm{C} 1$ to $\mathrm{F} 6=$ abundances of larval stages calyptopis 1 through calyptopis 3 and furcilia 1 through furcilia 6 ; and $N=$ sum of abundances of all stages. 

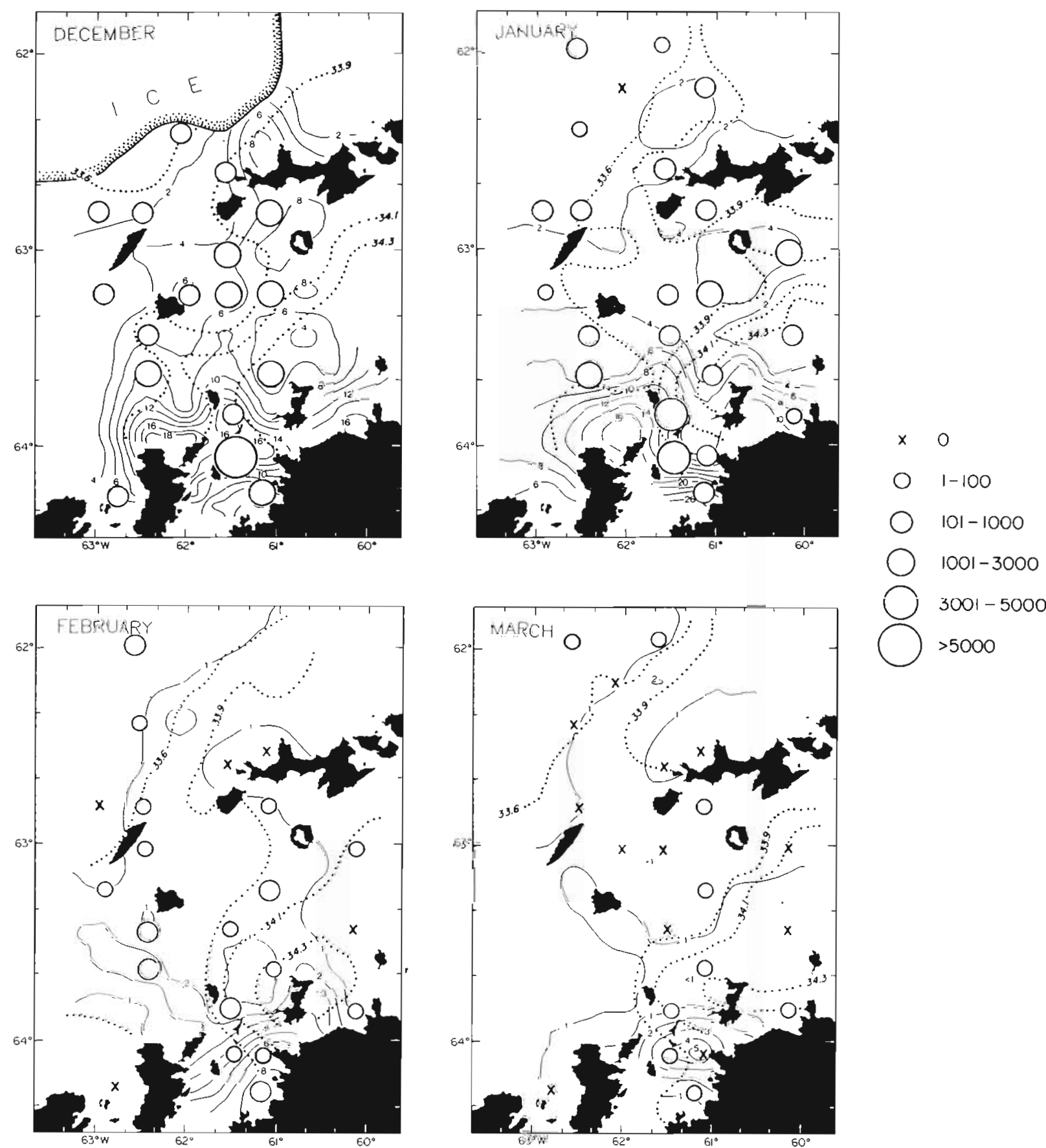

Fig. 2. Thysanoessa macrura. Abundance of larvae (ind. $1000 \mathrm{~m}^{-3}$ ) based on 'slow grid' samples from 0 to $200 \mathrm{~m}$. (a) December 1986, (b) January, (c) February and (d) March 1987 cruises. Contour lines give surface chlorophyll a concentrations in mg chl a m ${ }^{-3}$ (from Holm-Hansen \& Mitchell 1991). Dotted lines show surface salinity distribution (average of top 20 m; after Niiler et al 1991)

The mean length was calculated for larval, juvenile and adult Thysanoessa macrura from.

$$
\mathrm{L}=\left\{\left(\mathrm{L}_{1} \times 1\right)+\left(\mathrm{L}_{2} \times 2\right)+.+\left(\mathrm{L}_{31} \times 31\right)\right\} / \mathrm{N}
$$

where $\mathrm{L}=$ mean length; $L_{1}$ to $L_{31}=$ abundances of T. macrura size classes 1 through $31 \mathrm{~mm}$; and $\mathrm{N}=$ sum of abundance of all size classes. No multiple modality was observed for larvae, which demonstrates the occurrence of a single spawning period. For the purpose of distinguishing successions in larval stages, percent frequencies rather than numbers were plotted (Fig. 4).

Late calyptopis and early furcilia stages (C2 to F3) dominated in December. Stage C1 were also common, especially in the upper $100 \mathrm{~m}$. No eggs, nauplii, or 

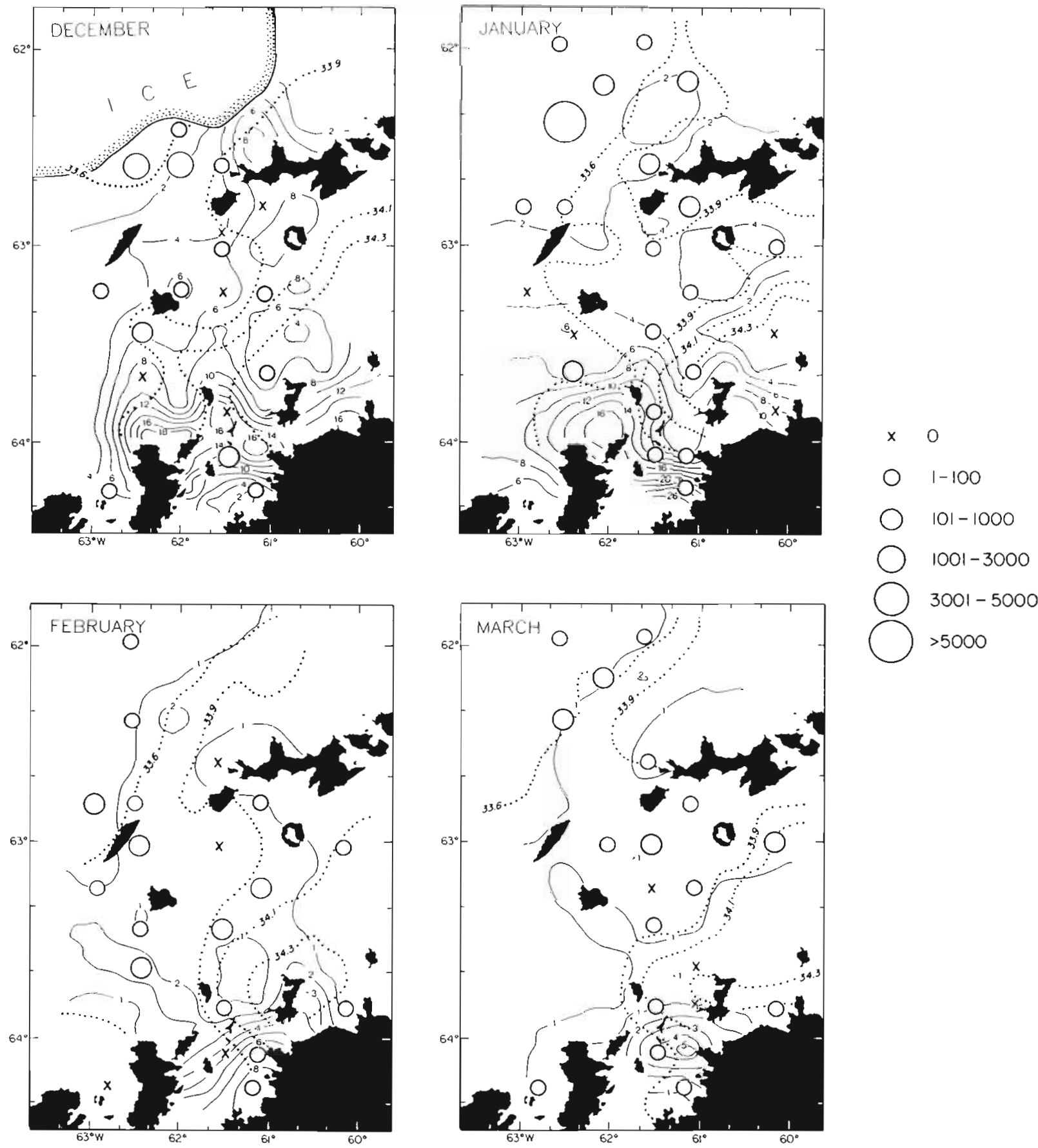

Fig. 3. Thysanoessa macrura. Abundance of adults. For legend see Fig. 2

metanauplii were found. The latest developmental stage found during December was F3, of which only a few were found in western Bransfield Strait.

Furcilia stages, in particular F2 and F3, were most abundant in January. Most remarkable is the fact that all developmental stages from $\mathrm{C} 1$ to $\mathrm{F} 6$ were present in January. C1 were again more abundant in the upper $100 \mathrm{~m}$. The mean stage was most advanced at stations in northern Bransfield Strait and north of Livingston Island.

In the period from February 26 to March 6, very few calyptopis stages were found; F1 and F2 were also rare. Most abundant were F6 and F5 stages, but F4 and F3 were also common. The mean stage did not vary much over the sampling grid, but earliest stages were found in Gerlache Strait. In late March the population was 


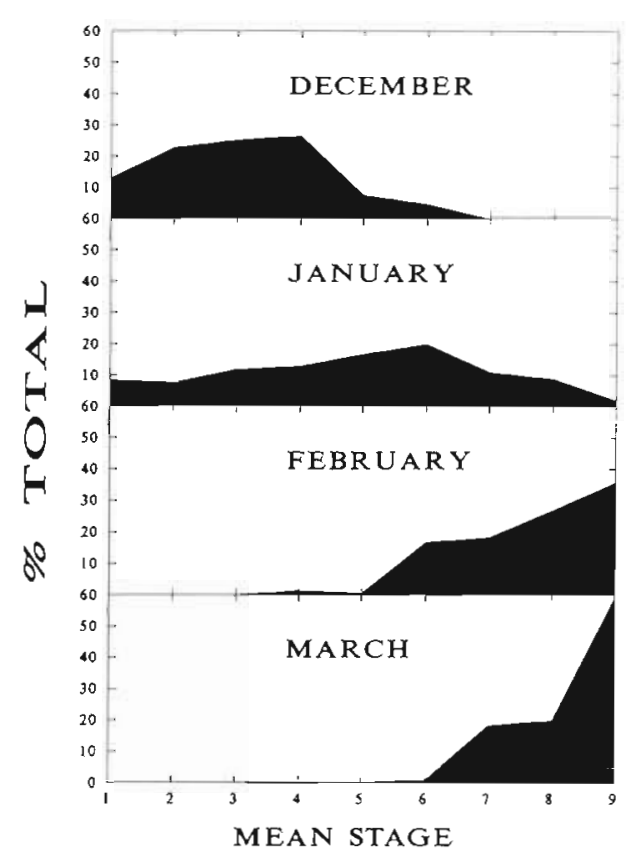

Fig. 4. Thysanoessa macrura. Mean stage frequency distribution of larvae during December 1986 through March 1987. Stages 1 to 3: Calyptopis 1-3, Stages 4 to 9: Furcilia 1-6

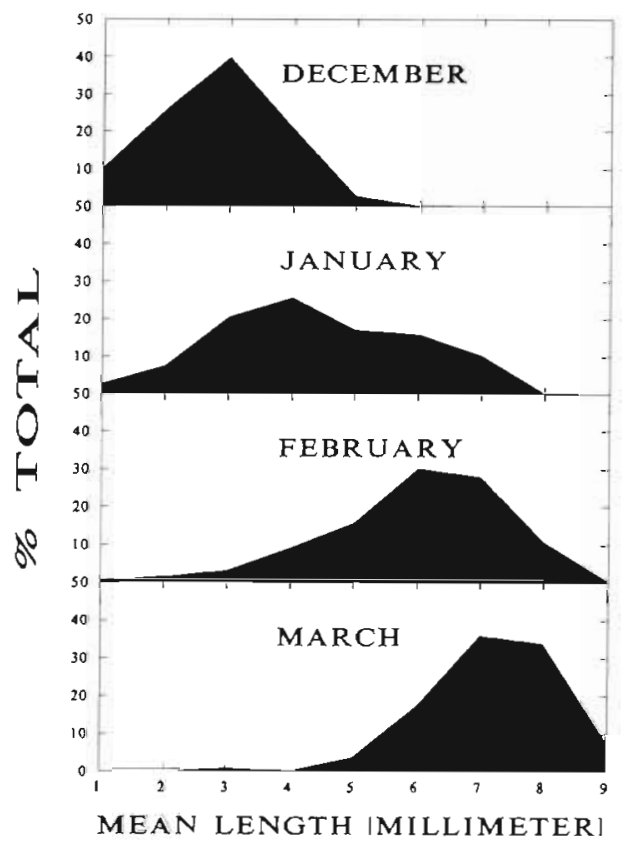

Fig. 5. Thysanoessa macrura. Mean length frequency distribution of larvae during December 1986 through March 1987

dominated by F6, while F4 and F5 were still abundant, as were juveniles.

The mean length frequency distribution of larvae (Fig. 5) was similar to the mean stage frequency distribution (Fig. 4). The single cohort grew from a mean length of $2.8 \mathrm{~mm}$ (SD $=0.6 \mathrm{~mm}$ ) in late December to $7.1 \mathrm{~mm}(\mathrm{SD}=0.8 \mathrm{~mm})$ at the end of March.

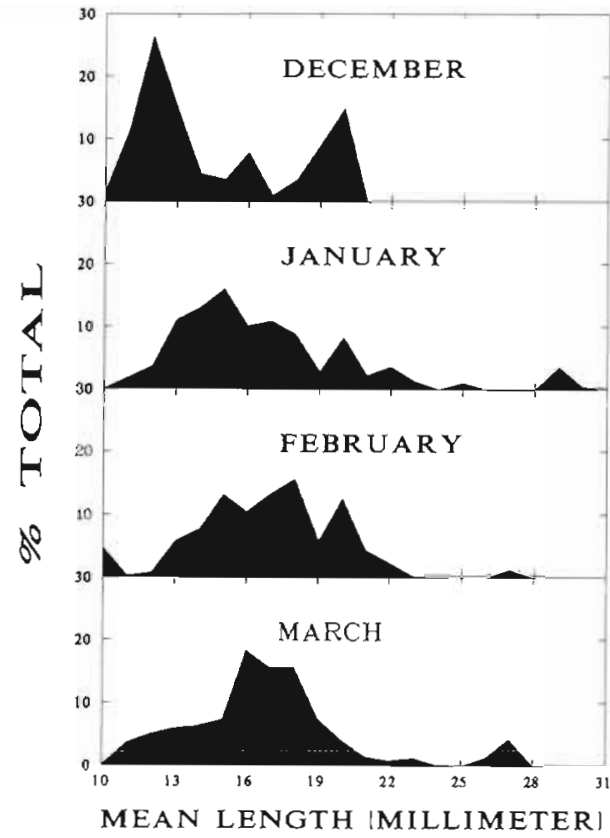

Fig. 6. Thysanoessa macrura. Mean body length frequency distribution of juveniles and adults during December 1986 through March 1987

The adult length frequency distribution of December showed bimodality, probably due to year classes (Fig. 6). While $12.0 \mathrm{~mm}$ long Thysanoessa macrura, presumably 1 yr old, dominated, individuals of $20.0 \mathrm{~mm}$ were also abundant. The size frequency plots of January and February show an increase in size. The bimodal length frequency distribution could still be seen in January and February, but to a lesser extent. Mean body length increased from $14.6 \mathrm{~mm}$ ( $\mathrm{SD}=3.1 \mathrm{~mm}$ ) in December to $16.9 \mathrm{~mm}(\mathrm{SD}=3.0 \mathrm{~mm})$ in March.

\section{Rates of growth and development}

The rate of increase in maturity stage over time, or development rate, was determined for Thysanoessa macrura from field samples by calculating the slope of the relation between mean stage versus period of sampling (Fig. 7). The development rate is given for the 3 regions, which were distinct in their water mass characteristics (Niiler et al. 1991) and in their phytoplankton biomass (Holm-Hansen \& Mitchell 1991): (1) Drake Passage in the northwest corner of the study site, (2) Bransfield Strait in the center and extending to the northeast, and (3) Gerlache Strait in the southern center of the survey area. Data from 3 depth strata $(0$ to $100 \mathrm{~m}, 100$ to $200 \mathrm{~m}$ and 0 to $200 \mathrm{~m}$; Fig. 7) suggest that development rate was faster during the early stages and decreased steadily with age. The stage duration of younger larvae was shorter than that of older stages. There were no obvious regional differences. 


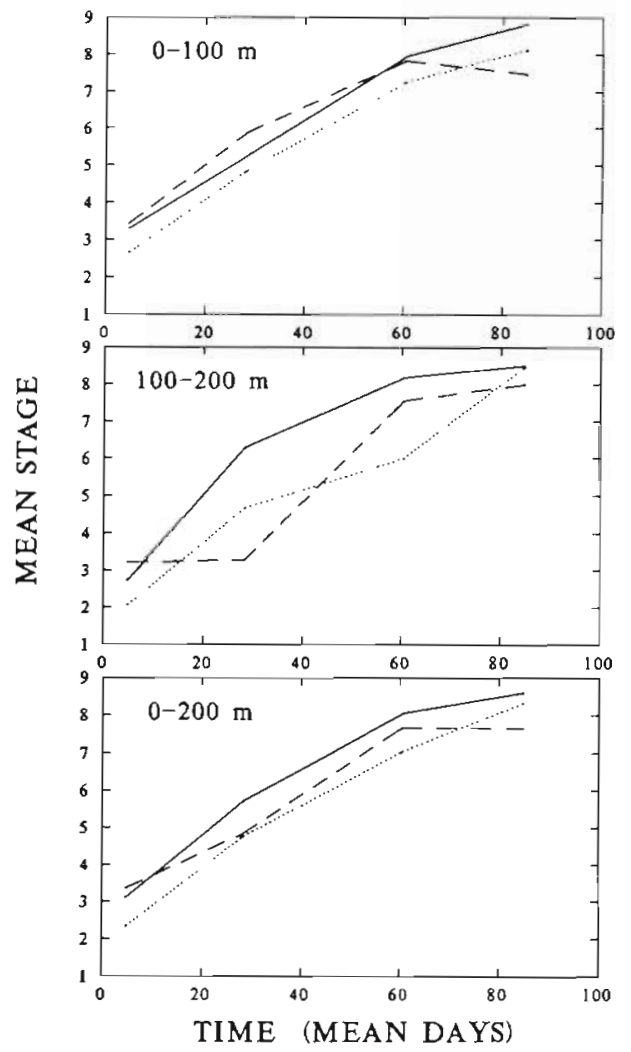

Fig. 7. Thysanoessa macrura development rates. Average mean stages for the Gerlache and Bransfield Straits and the Drake Passage are shown for 3 depth ranges. Days are mean values during December 1986 through March 1987 with the first day being the first day on station. (- -) Drake Passage; (-) Bransfield Strait; (…) Gerlache Strait. Mean stage: 1 to 3: Calyptopis $1-3 ; 4$ to 9 : Furcilia $1-6$

Proxy estimates of growth rates (increase in length over time) were calculated for Thysanoessa macrura from the 3 regions. The length at time $t, \mathrm{~L}(t)$, can be described from a model fitted to the observed sizes:

$$
\mathrm{L}(t)=\mathrm{L}_{\max }\left[1-\mathrm{e}^{(a-b t)}\right]
$$

where $L_{\max }=$ asymptotic length of an average $T$. macrura in the population; and $b=$ the coefficient at which the growth rate began to decrease. The constant $a$ was included to allow for a positive length at time $=$ 0 , which was the beginning of the sampling program.

Larval growth rates in Gerlache and Bransfield Straits were similar, but appear to have been slower in chlorophyll a-poor Drake Passage (Fig. 8). However, no statistically significant difference in growth rates was detected (ANOVA: $F_{\mathrm{s}}=1.08 \ll F_{0.05[2.81]}$ since $F_{0.05 \mid 2.120]}$ $=3.07$ ). Daily growth rates (increase in length) were highest in Gerlache Strait, intermediate in Bransfield Strait, and lowest in Drake Passage, and decreased in all 3 regions from December through March (Table 1). T. macrura developed from C2 to F6 in ca 90 d. From the data one would predict a single spawning period in the region during November 1986.

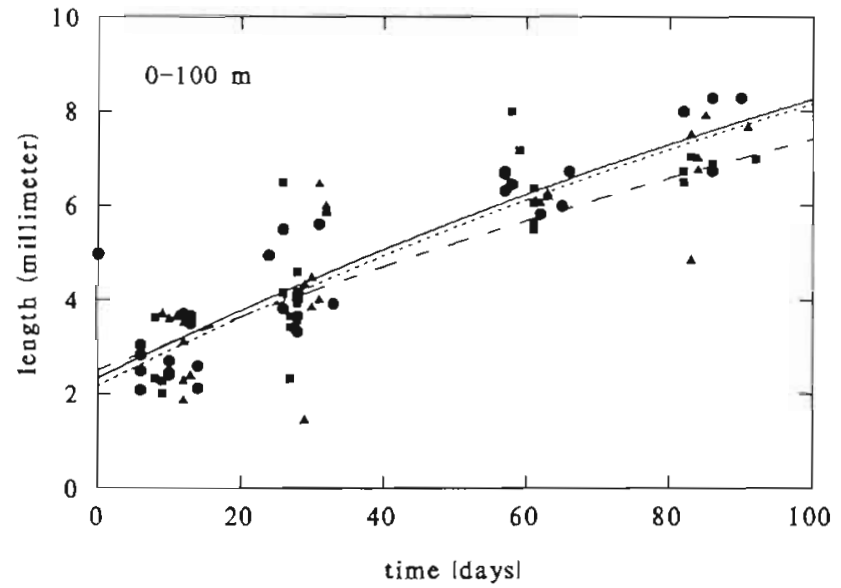

Fig. 8. Thysanoessa macrura growth rates. Mean body length at all stations for Gerlache and Bransfield Straits and Drake Passage are given. Time is given in days, starting with the first day of the cruise. An exponential model (Eq. 3) was fitted to the data. ( $--\Delta)$ Drake Passage; (- - Bransfield Strait; (-...) Gerlache Strait

Table 1 Thysanoessa macrura. Growth rates $\left(\mathrm{mm} \mathrm{d}^{-1}\right)$ of larvae in the western Bransfield Strait region during the period December 1986 through March 1987 calculated from: $\mathrm{L}_{(l)}=\mathrm{L}_{\max }\left[1-\mathrm{e}^{(a-b t)}\right]$ (see text for explanation)

\begin{tabular}{|lccc|}
\hline Slow survey & $\begin{array}{c}\text { Gerlache } \\
\text { Strait }\end{array}$ & $\begin{array}{c}\text { Bransfield } \\
\text { Strait }\end{array}$ & $\begin{array}{c}\text { Drake } \\
\text { Passage }\end{array}$ \\
\hline December & 0.073 & 0.072 & 0.057 \\
January & 0.068 & 0.067 & 0.054 \\
February & 0.056 & 0.056 & 0.046 \\
March & 0.050 & 0.049 & 0.042 \\
\hline
\end{tabular}

\section{DISCUSSION}

\section{Thysanoessa macrura distribution and abundance}

Water masses in the western Bransfield Strait region are quite complex. However, 5 regional water masses can be distinguished. The water in the northwestern part clearly belonged to the waters typical of the Southern Drake Passage. The water column in the southwestern corner was weakly stratified with a spatial transition to the most stratified upper layer water in Gerlache Strait. The fourth and fifth water masses were found around Low Island and Livingston Island (Amos et al. 1990, Niller et al. 1991). Two 'streams' flowed through the survey grid along the salinity contour lines (Figs. $2 \& 3$ ). One flowed from the southwest to the northeast (Bransfield Current), and was joined in the southwest by flow from Gerlache Strait. The other 'stream' flowed northward along the boundary of southern Drake Passage. Lagrangian drifters recently deployed (austral summer 1989) in southern Gerlache 
Table 2. Thysanoessa macrura. Abundance of larvae (C1 to F6) in 3 regions from December through March (1986-87). Abundances are given as individuals per $1000 \mathrm{~m}^{3}$ Mean: average number per $1000 \mathrm{~m}^{3}$; $\mathrm{SD}$ : standard deviation; $\mathrm{n}$ : number of samples

\begin{tabular}{|c|c|c|c|c|c|c|c|c|c|}
\hline & \multicolumn{3}{|c|}{ Gerlache Strait } & \multicolumn{3}{|c|}{ Bransfield Strait } & \multicolumn{3}{|c|}{ Drake Passage } \\
\hline & Mean & SD & $\mathrm{n}$ & Mean & $\mathrm{SD}$ & $\mathrm{n}$ & Mean & $\mathrm{SD}$ & $\mathrm{n}$ \\
\hline \multicolumn{10}{|l|}{ December } \\
\hline $0-100 \mathrm{~m}$ & 1626 & 1862 & 4 & 769 & 499 & 13 & 284 & 191 & 8 \\
\hline $100-200 \mathrm{~m}$ & 610 & 681 & 5 & 701 & 978 & 8 & 211 & 322 & 5 \\
\hline \multicolumn{10}{|l|}{ January } \\
\hline $0-100 \mathrm{~m}$ & 1262 & 1654 & 8 & 482 & 511 & 11 & 251 & 421 & 11 \\
\hline $100-200 \mathrm{~m}$ & 182 & 198 & 7 & 97 & 118 & 9 & 28 & 41 & 8 \\
\hline $200-2700 \mathrm{~m}$ & 61 & 0 & 1 & 42 & 42 & 2 & 2 & 1 & 5 \\
\hline \multicolumn{10}{|l|}{ February } \\
\hline $0-100 \mathrm{~m}$ & 55 & 134 & 6 & 199 & 243 & 11 & 13 & 26 & 7 \\
\hline $100-200 \mathrm{~m}$ & 76 & 133 & 3 & 22 & 26 & 9 & 30 & 39 & 6 \\
\hline $200-800 \mathrm{~m}$ & & & & 4 & 3 & 2 & & & \\
\hline \multicolumn{10}{|l|}{ March } \\
\hline $0-100 \mathrm{~m}$ & 30 & 29 & 6 & 4 & 11 & 7 & 8 & 17 & 8 \\
\hline $100-200 \mathrm{~m}$ & 21 & 19 & 5 & 3 & 6 & 5 & 0 & 0 & 5 \\
\hline $200-1000 \mathrm{~m}$ & & & & & & & 0 & 0 & 2 \\
\hline
\end{tabular}

Strait support the estimates from relative gcostrophic current (Niiler et al. 1990, 1991).

A gradient of decreasing phytoplankton biomass from Gerlache Strait into Bransfield Strait was observed persistently from December 1986 through March 1987 (Holm-Hansen \& Mitchell 1991). Phytoplankton biomass was highest in December and was still relatively high in January. A sharp decline was observed in February and March 1987. The waters of northern Gerlache Strait as well as those near Brabant Island, Hoseason Island, and Trinity Island consistently had the highest chlorophyll a concentrations (> $700 \mathrm{mg}$ $\mathrm{m}^{-2}$ in December; Holm-Hansen \& Mitchell 1991) (Figs. 2 \& 3).

High abundances of larval and adult Thysanoessa macrura have been frequently reported (Hempel \& Marschoff 1980, Weigmann-Haas \& Haas 1980, Hempel 1981, Piatkowski 1985a). Most of these investigations covered broad regions in the Atlantic sector of the Southern Ocean (Hempel \& Marschoff 1980), Scotia Sea (Makarov 1979a, Weigmann-Haas \& Haas 1980), or Drake Passage and Bransfield Strait (Kittel \& Stepnik 1983. Piatkowski 1985a).

The results of this study with its unique 4 sequential surveys show highest larval abundances of Thysanoessa macrura in Gerlache Strait during December and January. This coincided temporally and spatially with the area in which the highest phytoplankton biomass was found (Holm-Hansen \& Mitchell 1991). The Bransfield Current is likely to have advected the planktonic larval stages of $T$. macrura from Gerlache Strait to the northeast into Bransfield Strait, where intermediate abundances were found in December and January
(Table 2). Low abundances of larval $T$. macrira were consistently found in the offshore part of the study area in Drake Passage (Table 2). Kittel \& Stepnik (1983) reported highest abundances of $T$. macrura larvae north of the South Shetland Islands and in the water of the West Wind Drift, and lower abundances of larvae for the region near Smith Island and west of Livingston Island, in particular.

A sharp decline in the abundance of Thysanoessa macrura larvae occurred in February and March 1987 which coincided with greatly reduced phytoplankton biomass (Fig. 2, Table 2). While in December larval stages were found at all stations, in March larvae were found at $42 \%$ of the stations sampled. Most stations in the northwestern part of the survey area did not reveal any $T$. macrura larvae or only very low abundances (Table 2). Juvenile abundances were also low in March; the decline must be due to mortality or to advection out of the area investigated.

The distribution of adult Thysanoessa macrura was more even than that of the larvae. Adult abundances did not vary as much as abundances of early life stages during the period from December 1986 to the end of March 1987. The greatest abundances were never found in Gerlache Strait (Table 3), but rather in Drake Passage waters (Table 3 ). The ratio of females per male was greatest in Drake Passage, with a mean of 2.5 during December 1986 through March 1987 The sex ratio was lowest in Gerlache Strait (1.2) and intermediate in Bransfield Strait (1.5). However, these differences were not significant at $95 \%$ in a median test (Zar 1974) (Table 4); they show a trend similar to that described by Kittel \& Stepnik (1983), who found the 
Table 3. Thysanoessa macrura. Abundances of juveniles and adults ( $\geq 10 \mathrm{~mm}$ length) in 3 regions from December through $\mathrm{March}$ (1986-87). Abundances are given as individuals per $1000 \mathrm{~m}^{3}$ Mean: average number per $1000 \mathrm{~m}^{3}$; SD: standard deviation; $\mathrm{n}$ : number of samples

\begin{tabular}{|c|c|c|c|c|c|c|c|c|c|}
\hline & \multicolumn{3}{|c|}{ Gerlache Strait } & \multicolumn{3}{|c|}{ Bransfield Strait } & \multicolumn{3}{|c|}{ Drake Passage } \\
\hline & Mean & $\mathrm{SD}$ & $n$ & Mean & $\mathrm{SD}$ & $\mathrm{n}$ & Mean & $\mathrm{SD}$ & $\mathrm{n}$ \\
\hline \multicolumn{10}{|l|}{ December } \\
\hline $0-100 \mathrm{~m}$ & 19 & 27 & 4 & 27 & 64 & 13 & 99 & 36 & 8 \\
\hline $100-200 \mathrm{~m}$ & 4 & 4 & 5 & 25 & 36 & 8 & 750 & 716 & 4 \\
\hline \multicolumn{10}{|l|}{ January } \\
\hline $0-100 \mathrm{~m}$ & 3 & 4 & 8 & 42 & 60 & 10 & 647 & 1813 & 11 \\
\hline $100-200 \mathrm{~m}$ & 23 & 28 & 7 & 79 & 60 & 10 & 85 & 201 & 8 \\
\hline $200-2700 \mathrm{~m}$ & & & & & & & 1 & 1 & 5 \\
\hline \multicolumn{10}{|l|}{ February } \\
\hline $0-100 \mathrm{~m}$ & 8 & 6 & 7 & 111 & 152 & 10 & 41 & 80 & 7 \\
\hline $100-200 \mathrm{~m}$ & 19 & 12 & 3 & 43 & 100 & 9 & 75 & 107 & 7 \\
\hline $200-800 \mathrm{~m}$ & & & & 1 & 1 & 2 & & & \\
\hline \multicolumn{10}{|l|}{ March } \\
\hline $0-100 \mathrm{~m}$ & 3 & 5 & 5 & 67 & 102 & 6 & 29 & 40 & 7 \\
\hline $100-200 \mathrm{~m}$ & 2 & 2 & 5 & 182 & 286 & 5 & 142 & 273 & 5 \\
\hline $200-1000 \mathrm{~m}$ & & & & & & & 3 & 3 & 2 \\
\hline
\end{tabular}

greatest sex ratio in Drake Passage (6.1) and a lower ratio in Bransfield Strait (1.8) in February and March 1981 .

The ratio of larvae to adults ( $\geq 14 \mathrm{~mm}$ ) was not homogeneous throughout the survey area. A median test (Zar 1974) showed that the number of larvae per adult was significantly greater in Gerlache Strait than in Bransfield Strait or Drake Passage. However, there were no significant differences between Drake Passage and Bransfield Strait (Table 5). A similar phenomenon was observed for Euphausia superba during the same study (Brinton 1991).

A developmental ascent has been proposed for Thysanoessa macrura (Makarov 1979a). Spawning occurs in the water column; eggs sink, and hatch at depth. Highest abundances of $T$. macrura nauplii and metanauplii were found between 500 and $1000 \mathrm{~m}$ in the Scotia Sea in December 1974 through January 1975 and a development time of 15 to $20 \mathrm{~d}$ from egg to $\mathrm{C} 2$ was reported (Makarov 1979a). However, this development period was based on cultivation experiments and plankton catches of various euphausiids in temperate waters (Heegaard 1948, Mauchline 1959) and might be longer in Antarctica.

\section{Diel vertical distribution and migration}

The vertical distribution of Thysanoessa macrura observed in this study was similar to that reported elsewhere (e.g. Makarov 1979a, Kittel \& Stepnik 1983, Loeb \& Shulenberger 1987). Adults and larvae were most abundant in the upper $200 \mathrm{~m}$; very few individu-
Table 4. Thysanoessa macrura. Median test of sex ratios (females per male) in 3 regions near the Antarctic Peninsula ns: not significant

\begin{tabular}{|c|c|c|c|}
\hline Region & $\mathrm{n}$ & Chi square & $\begin{array}{l}\text { Probability } \\
(95 \%)\end{array}$ \\
\hline $\begin{array}{l}\text { Gerlache Strait/ } \\
\text { Bransfield Strait }\end{array}$ & 10 & 1.338 & ns \\
\hline $\begin{array}{l}\text { Bransfield Strait/ } \\
\text { Drake Passage }\end{array}$ & 30 & 0.634 & ns \\
\hline $\begin{array}{l}\text { Drake Passage/ } \\
\text { Gerlache Strait }\end{array}$ & 25 & 0.093 & ns \\
\hline
\end{tabular}

Table 5. Thysanoessa macrura. Median test of larvae to adults $(\leq 14 \mathrm{~mm}$ ) ratios (females per male) in 3 regions near the Antarctic Peninsula. ns: not significant

\begin{tabular}{|c|c|c|c|}
\hline Region & $\mathrm{n}$ & Chi square & $\begin{array}{c}\text { Probability } \\
\quad(95 \%)\end{array}$ \\
\hline $\begin{array}{l}\text { Gerlache Strait/ } \\
\text { Bransfield Strait }\end{array}$ & 43 & 3.988 & $<0.05$ \\
\hline $\begin{array}{l}\text { Bransfield Strait/ } \\
\text { Drake Passage }\end{array}$ & 65 & 0.308 & ns \\
\hline $\begin{array}{l}\text { Drake Passage/ } \\
\text { Gerlache Strait }\end{array}$ & 70 & 6.636 & $<0.01$ \\
\hline
\end{tabular}

als of any stage were found at greater depths in the few deeper samples. Larval stages C1 to F6 were significantly more abundant in the upper $100 \mathrm{~m}$ than in the 100 to $200 \mathrm{~m}$ depth interval (Mann-Whitney $U$-test, $\mathrm{p}<0.05$ ). Abundances of nauplii and metanauplii have been reported to be greatest at depths of 200 to $1000 \mathrm{~m}$ (Makarov 1979a) but none were found in this study. $T$. 
macrura begins spawning early in the austral summer (Makarov 1979a, Kittel 1988). By late December, the beginning of this study, the larvae had already outgrown the naupliar and metanaupliar stages.

Diel vertical migration between the 0 to 100 and the 100 to $200 \mathrm{~m}$ layers by larvae and adults of Thysanoessa macrura was not detected in this study. Near South Georgia in August, T. macrura were significantly more abundant in the upper $250 \mathrm{~m}$ (Ward et al. 1990) Kittel \& Stepnik (1983) found a higher ratio of adults to larvae between 100 and $300 \mathrm{~m}$ in samples taken at night while daytime catches showed few adults in either stratum. Greater night than day catches of adult $T$. macrura in the top $80 \mathrm{~m}$ were found near Elephant Island by Loeb \& Shulenberger (1987), who proposed diel vertical migration or reduced net avoidance at night as an explanation. No significant differences in day vs night catches in abundance were found in the present study. However, further investigations with greater vertical and temporal resolution are necessary to better understand the diel behavior of $T$. macrura.

\section{Development and growth rates in Drake Passage, Bransfield and Gerlache Straits}

Whether the development of euphausid larvae is isochronal or age dependent has been debated. Pillar $(1984,1985)$ reported no dependence on age of moult frequency of C3 through F6 stages of Euphausia lucens and Nyctiphanes capensis. However, data of other workers indicate that the development of euphausids is not isochronal, but changes from shorter stage durations of early larval stages to longer intermoult periods of older and larger larvae (Heegaard 1948, Mauchline 1959, 1977, Ikeda 1985, McClatchie 1988, Huntley \& Brinton 1991). Euphausiids grow to a maximum body length, but continue moulting throughout their lives (Mauchline 1977). The equation (Eq. 2) used here to model the growth of larval Thysanoessa macrura was chosen because it best describes the underlying biology. The mean body length in each sample was plotted and the model fitted to these mean lengths. The asymptotic length attained by an average $T$. macrura was calculated from the field samples.

A distinction should be made between individual growth rates and the growth rate of cohorts. Individual growth rates are affected by food limitation as shown in laboratory experiments (Ikeda 1984, 1986), but increased mortality of slower-developing larvae causes the growth rate of the cohort to appear greater.

The growth rates of Thysanoessa macrura cohorts in the 3 regions of distinctly different phytoplankton concentration were compared using the log-transformed model. A statistically significant difference of growth rates between cohorts from the phytoplankton-rich Gerlache and Bransfield Straits and those from chlorophyll a-poor Drake Passage (Holm-Hansen \& Mitchell 1991) was not detected. This suggests that the growth rate of $T$. macrura cohorts was not limited by phytoplankton food in these regions. However, this is valid only for the survivors. The decrease in abundance of larval T. macrura might be linked to the observed decline in phytoplankton abundance.

Laboratory starvation experiments with Euphausia superba demonstrated that early calyptopis stages were more susceptible to starvation and death than older larvae (Ikeda 1984). Prolonged stage duration as a result of inadequate food could cause increased mortality for slower-developing larvae due to longer exposure of early stages to predation. Stage-specific mortality of copepodite instars tends to drive the mean development rate of cohorts towards development rates greater than those expected based on food availability (Lopez 1991). This could explain reduced abundances under unfavorable conditions but might not affect overall development rates of cohorts. Resource limitation of development rates may thus be undetectable at the level of populations.

\section{CONCLUSION}

Thysanoessa macrura was the most abundant euphausiid in the western Bransfield Strait region during December 1986 through March 1987. Females in their second and third year spawned during a discrete period prior to 15 December 1986, the beginning of this study. Adult $T$. macrura were more abundant at the offshore stations in Drake Passage, where larval abundances were low. Greatest abundances of $T$. macrura larvae coincided spatially and temporally with a phytoplankton bloom in Gerlache Strait in December and extended into southwestern Bransfield Strait by January 1987 . The growth rate of $T$. macrura cohorts was not correlated with chlorophyll a concentration. T. macrura larvae developed from calyptopis 2 in late December to furcilia 6 by the end of March. Diel vertical migration of adult and larval $T$. macrura was not detected in this study, but the coarse vertical sampling might have made the detection of diel variations impossible

The life history of Thysanoessa macrura is still only partly known. Preferred spawning regions have not been located and winter observations of the distribution as well as the physiological state and behavior of $T$. macrura appear not to exist. However, the high biomass and widespread distribution of this euphausiid species in Antarctic waters make it likely to have been of underestimated importance in the marine ecosystem and thus deserving of more attention. 
Acknowledgements. I thank the RACER personnel, the officers and crew members on board the RV 'Polar Duke' and the Antarctic Services personnel for their expert support. I also thank the scientists who reviewed the manuscript and offered valuable suggestions, including $M$. Huntley, E. Brinton, and M. Unson. This work was accomplished with support from National Science Foundation grant DPP 88-17779 to Mark Huntley and Edward Brinton

\section{LITERATURE CITED}

Amos, A. F., Jacobs, S. S., Hu, J. H. (1990). RACER: hydrography of the surface waters during the spring bloom in the Gerlache Strait. Antarct. J. U.S. 25: 131-134

Baker, A. C. (1954). The circumpolar continuity of Antarctic plankton species. 'Discovery' Rep. 27: 201-218

Brinton, E. (1985). The oceanographic structure of the eastern Scotia Sea - III. Distribution of euphausiid species and their developmental stages in 1981 in relation to hydrography. Deep Sea Res. 32: 1153-1180

Brinton, E. (1991). Distribution and population structures of immature and adult Euphausia superba in the western Bransfield Strait region during the 1986-87 summer. Deep Sea Res. 38: 1169-1194

Brinton, E., Loeb, V J., Macaulay, M. C., Shulenberger, E. (1987). Variability of Euphausia superba populations near Elephant Island and the South Shetlands: 1981 vs. 1984 Polar Biol. 7: 345-362

Conover, R. J., Huntley, M. E. (1991). Zooplankton and seaice: distribution, adaptations to seasonally limited food, metabolism, growth patterns and life cycle strategies in polar seas. J. mar. Syst. 2: 1-41

Daly, K.M., Macaulay, M. C. (1988). Abundance and distribution of krill in the ice edge zone of the Weddell Sea, austral spring 1983. Deep Sea Res. 35: 21-41

El-Sayed, S. (1984). Productivity of the Antarctic Waters - a reappraisal. In: Holm-Hansen, O., Bolis, L., Gilles, R. (eds.) Marine phytoplankton productivity. Lecture notes on coastal and estuarine studies. Vol. 8. Springer, Berlin, p. 19-34

Fevolden, S. E. (1979). Investigations on krill (Euphausiacea) sampled during the Norwegian Antarctic Research Expedition 1976-77. Sarsia 64: 189-198

Hagen, W. (1988). Zur Bedeutung der Lipide im antarktischen Zooplankton. Ber. Polarforsch. 49: 1-129

Heegaard, P. (1948). Larval stages of Meganyctiphanes (Euphausiacea) and some general phylogenetic remarks. Meddr Kommn. Danm. Fisk.-og Havunders. (Ser Plankton) 5: 1-27

Hempel, I. (1981). Euphausid larvae in the Scotia Sea and adjacent waters in the summer 1977/78. Meeresforsch. 29 53-59

Hempel, G. (1985). Antarctic marine food webs. In: Siegfried, W. R., Condy, P. R., Laws, R. M. (eds.) Antarctic nutrient cycles and food webs. Springer, p. 266-270

Hempel, I., Hempel, G. (1982). Distribution of euphausiid larvae in the southern Weddell Sea. Meeresforsch. 29: 253-266

Hempel, I., Marschoff, E. (1980). Euphausid larvae in the Atlantic sector of the Southern Ocean. Meeresforsch. 28: $32-47$

Hewes, C. D., Holm-Hansen, O., Sakshaug, E. (1985). In: Siegfried, W. R. Condy, P. R., Laws, R. M. (eds.) Antarctic nutrient cycles and food webs. Springer, Berlin, p. 277-283

Holm-Hansen, O., Mitchell, B. G. (1991). Spatial and temporal distribution of phytoplankton and primary production in the western Bransfield Strait region. Deep Sea Res. 38 $961-980$

Hopkins, T L. (1985). Food web of an Antarctic midwater ecosystem. Mar Biol. 89: 197-212

Hopkins, T L., Torses, J. J. (1988). The zooplankton community in the vicinity of the ice edge, Western Weddell Sea. March 1986. Polar Biol. 9: 79-87

Huntley, M. E., Brinton, E. (1991). Mesoscale variation in growth and early development of Euphausia superba Dana in the western Bransfield Strait region. Deep Sea Res. 38: 1213-1240

Huntley, M. E., Niiler, P., Holm-Hansen, O., Karl, D. M (1987). RACER: an interdisciplinary field study. Antarct. J. U.S. 22(5): $135-137$

Huntley, M. E., Karl, D. M., Niiler, P., Holm-Hansen, O. (1991). Research on Antarctic Coastal Ecosystem Rates (RACER): an interdisciplinary field experiment. Deep Sea Res. 38: 911-942

Ikeda, T (1984). Development of the larvae of the Antarctic krill (Euphausia superba Dana) observed in the laboratory. J. exp. mar. Biol. Ecol. 75: 107-117

Ikeda, T. (1986). Preliminary observations on the development of the larvae of Euphausia crystallorophias Holt and Tattersall in the laboratory. Mem. Natn. Inst. Polar Res., Tokyo 40: $183-186$

Kittel, W. (1988). Euphausiid larvae in the Scotia Front west of Elephant Island (BIOMASS III, October-November 1986). Pol. Polar Res. 9: 305-314

Kittel, W. Stepnik, R. (1983). Distribution of Euphausia crystallorophias, E. frigida, E. triacantha and Thysanoessa macrura (Crustacea, Euphausiacea) in the southern Drake Passage and Bransfield Strait in February and March 1981. Pol. Polar Res. 4: 7-19

Kittel, W., Witek, Z., Czykieta, H. (1985). Distribution of Euphausia frigida, Euphausia crystallorophias, Euphausia triacantha and Thysanoessa macrura in the southern part of Drake Passage and in the Bransfield Strait during the 1983-1984 austral summer BIOMASS-SIBEX. Pol. Polar Res. (1/2): 133-149

Knox, G. A. (1970). Antarctic marine ecosystems. In: Holdgate, M. W. (ed.) Antarctic ecology, Vol. 1. Academic Press, New York, p. 69-96

Lancraft, T M., Torres, J. J., Hopkins, T L. (1989). Micronekton and macrozooplankton in the open waters near the Antarctic ice edge zones (AMERIEZ 1983 and 1986). Polar Biol. 9: 225-233

Loeb, V. J., Shulenberger, E. (1987). Vertical distributions and relations of euphausiid populations off Elephant Island, March 1984. Polar Biol. 7: 363-373

Lomakina, N. B. (1964). The euphausiid fauna of the Antarctic and notal regions. In: Biological Reports of the Soviet Antarctic Expedition 1955-58', Vol. 2, p. 260-342. Israel Programme for Scientific Translation, Jerusalem

Lopez, M. D. G. (1991). Molting and mortality depend on age and stage in naupliar Calanus pacificus: implications for development time of field cohorts. Mar. Ecol. Prog. Ser 75: $79-89$

Makarov, R. R. (1979a). Larval distribution and reproductive ecology of Thysanoessa macrura (Crustacea: Euphausiacea) in the Scotia Sea. Mar. Biol 52: 377-386

Makarov, R. R. (1979b). Size composition and conditions of existence of Euphausia superba Dana (Crustacea: Euphausiacea) in the eastern part of the Pacific sector of the Southern Ocean. Oceanology 19: 582-585

Makarov, R. R. (1982). Ontogenetichskie migratsii evfauziid Antarktiki. Antarktika; doklady komisii (1982) 21: 118-132 (In Russian) 
Marr, J. W. S. (1962). The natural history and geography of Antarctic krill (Euphausia superba Dana). Discovery Rep. 32: $33-464$

Marschall, H. P. (1988). The overwintering strategy of Antarctic krill under pack-ice of the Weddell Sea. Polar Biol. 9: 129-135

Mauchline, J. (1959). The development of the Euphausiacea (Crustacea), especially that of Meganyctiphanes norvegica (M. Sars). Proc. zool. Soc. Lond. 132: 627-639

Mauchline, J. (1977). Growth and moulting of crustacea, especially euphausiids. In: Anderson, N. R., Zahuranec, B. J (eds.) Oceanic sound scattering prediction. Plenum Press, New York, p. 401-422

Mauchline, J., Fisher, L. R. (1969). The biology of euphausiids. In: Russel, F. S., Yonge, M. (eds.) Adv. mar. Biol. 7: 1-454

McClatchie, S. (1988). Food-limited growth of Euphausia superba in Admiralty Bay, South Shetland Islands, Antarctica. Cont. Shelf Res. 8: 329-345

Nemoto, T. (1966). Thysanoessa euphausiids, comparative morphology, allomorphosis and ecology. Sci. Rep. Whales Res. Inst. 20: 109-155

Nemoto, T., Harrison, G. (1981). High latitude ecosystems. In: Longhurst, A. R. (ed.) Analysis of marine ecosystems. Academic Press, London, p. 95-126

Niiler, P., Illeman, J., Hu, J.-H. (1990). Lagrangian drifter observations of surface circulation in the Gerlache and Bransfield Straits. Antarct. J U.S. 25: 134-137

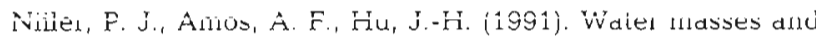
$200 \mathrm{~m}$ relative geostrophic circulation in the western Bransfield region. Deep Sea Res. 38: 943-960

Piatkowski, U. (1985a). Maps of the geographical distribution of macrozooplankton in the Atlantic sector of the Southern Ocean. Ber. Polar Res. 22: 1-55

Piatkowski, U. (1985b). Distribution, abundance and diurnal migration of macrozooplankton in Antarctic surface waters. Meeresforsch. 30:264-279

Pillar, S. C. (1984). Laboratory studies on the larval growth

This article was submitted to the editor and development of Euphausia lucens (Euphausiacea). S. Afr. J. mar Sci. 2: 43-48

Pillar, S. C. (1985). Laboratory studies on the larval growth and development of Nyctiphanes capensis (Euphausiacea). J Plankton Res. 7: 223-240

Pires, A. M. S. (1986). Vertical distribution of the euphausiid larvae (Crustacea) in the Bransfield Strait during the 1st Brazilian Antarctic Expedition (summer 1982/83). An. Acad. Bras. Cienc. 58: 43-51

Reinhardt, S. B., Van Vleet, E. S. (1986). Lipid composition of twenty two species of Antarctic midwater zooplankton and fish. Mar. Biol. 91: 149-159

Rustad, D. (1930). Euphausiacea, with notes on their biogeography and development. Scient. Res. Norw. Antarct. Exped. 5: 1-53

Rustad, D. (1934). On the Antarctic euphausiid from the 'Norwegia' Expedition 1929-30 and 1930-31. Scient. Res. Norw. Antarct. Exped. 12: 1-53

Ruud, J. H. (1932). On the biology of Southern Euphausiidae. Hvalråd. Skr. 2: 42-48.

Smetacek, V., Scharek, R., Nöthig, E. M. (1990). Seasonal and regional variation in the pelagial and its relationship to the life history of krill. In: Kerry, K. R., Hempel, G. (eds.) Antarctic ecosystems. Springer Verlag, Berlin p. 103-114

Smith, S. L., Schnack-Schiel, S. B. (1990). Polar zooplankton. In: Smith, W (ed.) Polar oceanography, Part B: Chemistry, biology, and geology. Academic Press, New York, p. $527-597$

Ward, P., Atkinson, A., Peck, J. M., Wood, A. G. (1990). Euphausid life cycles and distribution around South Georgia. Antarct. Sci. 2: 43-52

Weigmann-Haas, R., Haas, G. (1980). Geographische Verbreitung und vertikale Verteilung der Euphausiacea (Crustacea) während der Antarktis-Expedition 1975/76. Meeresforsch. 28: 19-31

Zar, J. H. (1984). Biostatistical analysis, 2nd edn. Prentice Hall, Englewood Cliffs, NJ

Manuscript furst received: September 11, 1991

Revised version accepted: April 22, 1992 